\title{
Palaeoweathering characteristics of an intrabasaltic red bole of the Deccan Flood Basalts near Shrivardhan of western coast of India
}

\author{
M R G SAYYed ${ }^{1, *}$, R G PARDEShi ${ }^{2}$ and R Islam ${ }^{3}$ \\ ${ }^{1}$ Department of Geology, Poona College, Camp, Savitribai Phule University of Pune, Pune 411 001, India. \\ ${ }^{2}$ Department of Geology, Fergusson College, Savitribai Phule University of Pune, Pune 411 004, India. \\ ${ }^{3}$ Wadia Institute of Himalayan Geology, Dehara Dun 248001, India. \\ *Corresponding author.e-mail: mrgsayyed@yahoo.com
}

An intrabasaltic red bole horizon is studied for its weathering characteristics with respect to the underlying and overlying basalts. The study indicates that all the three units have been considerably weathered; the red bole unit, however shows some distinctive characteristics. The red boles show a higher cation exchange capacity (CEC) and lower sodium adsorption ratio (SAR) and organic carbon (OC) as compared to the weathered basalts. The lower values of $\mathrm{Al}_{2} \mathrm{O}_{3}, \mathrm{TiO}_{2}$ and $\mathrm{Fe}_{2} \mathrm{O}_{3}(\mathrm{~T})$ in red boles indicate their lesser weathering than the underlying and overlying basalts, which is further corroborated by the weathering intensity measured by the indices like chemical index of alteration (CIA) and statistical empirical index of chemical weathering $(\mathrm{W})$. It is also evident that the red bole samples show more retention of original mafic and felsic components. While $\mathrm{K}_{2} \mathrm{O}$ exhibits an erratic behaviour, the $\mathrm{MgO}$ and $\mathrm{CaO}$ do not show much leaching in red boles. Lesser leaching and salinity in the red boles is indicated by the higher values of calcification and lower values of salinization. The $\mathrm{SiO}_{2}-\mathrm{Al}_{2} \mathrm{O}_{3}-\mathrm{Fe}_{2} \mathrm{O}_{3}$ plot indicates that red bole samples are close to the basalt field, while the weathered upper basalt is more kaolinized than the weathered lower basalt. These observations reveal that the post-formational weathering processes have least affected the original palaeoweathering characters of the red bole horizon and hence the intrabasaltic palaeosols (weathering horizons) can effectively be used to constrain the palaeoweathering and palaeoclimates during the continental flood basalt episodes in the geologic past.

\section{Introduction}

Large igneous provinces (LIPs) covering millions of square kilometers of the earth surface (Coffin and Eldholm 1994) have been widely distributed, both spatially and temporally, amongst which some are submarine and others are terrestrial (Jerram and Widdowson 2005). The question is whether or not these eruptions changed the climate leading to the mass extinctions, as many considered the Continental Flood Basalt Volcanism responsible for most extinction events (McLean 1985; Courtillot 1990;
Courtillot et al. 1996). The comparison of the ages of flood basalt provinces and mass extinction events (Wignall 2001) provide the most compelling evidence for a link between volcanism and extinctions. Since the chemical weathering is a response to the contemporaneous reactions between the meteoric water equilibrated with the atmospheric gases and the protoliths, ancient soils have been largely used to understand the palaeoclimates. Clayey or earthy red horizons are known to be intercalated in the flood basalts from several parts of the world although their origin has been a matter of debate.

Keywords. Bole beds; palaeosol; palaeoclimates; palaeoweathering; geochemistry; Deccan Traps. 
Some describe them as meteoric weathering products (palaeosols) or saprolites and others consider them to be formed as a result of the hydrothermal alteration of basalt. In the case of bole horizons from the Deccan Volcanic Province, there are different views regarding their origin and the following origins have been suggested:

- Intertrappean sediments (Fermor 1927; Pascoe 1973);

- weathered products of basalts (Lyell 1958; Agashe and Gupte 1968);

- submarine pelagic deposits (Shepard 1963; Inamdar and Darshan Kumar 1994); and

- weathered pyroclastics (Wilkins et al. 1994; Mohapatra and Nair 1996).

Irrespective of the origin of the bole beds, the above information creates an understanding of the chemical weathering processes of Deccan basalts under different weathering regimes (Wilkins et al. 1994) irrespective of their genetic modes. This is particularly true when the weathering profiles developed in the quiescence periods of the flood basalt eruptions can get preserved more easily between successive lava episodes. Therefore, such continental palaeoweathering records with strong mineralogical and geochemical fingerprints are immensely important to understand the global palaeoclimates (Widdowson 1997a, b; Thiry et al. 1999). In the present study, an intrabasaltic bole bed developed during the Maas-

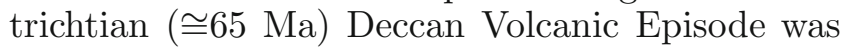
studied in relation to the overlying and underlying basalts.

\section{Intrabasaltic bole beds and palaeoclimates}

Palaeoclimatic records are necessary in predicting the future climatic changes on the earth as these unveil the changes in the atmospheric chemistry and the response of natural systems. There were periods when the climates were significantly cooler and warmer than the present, as recorded in the earth's history, in response to the globally distributed climate change events, which affected the oceanic, atmospheric, and terrestrial events. These periods offer a unique opportunity in modelling and predicting the global climate response to enhanced greenhouse gases as the variations in the atmospheric carbon dioxide concentrations are now linked, on almost every timescale, to extreme past climate change record (global cooling to global warming). Thus in order to develop a unifying global climate change model it is important to understand the terrestrial events as well (Sayyed and Hundekari 2006). The study of palaeosols carries great potential as their mineralogy, chemistry, and weathering pattern can be used in inferring the palaeoclimatic conditions. Further, the interpretative value of basalt-derived palaeosols is increased because of the fairly homogeneous nature of the basaltic parent-material and also, the palaeosol characteristics can be related to contemporary soil genesis from basalt. Thus intrabasaltic palaeosols provide high-resolution palaeoclimatic records of terrestrial environment if the ages of the associated basalt flows can be determined.

\section{Area of study}

Shrivardhan is an important township in the Raigad district of Maharashtra state in India. This region is an important part of Deccan Volcanic Province as it is supposed to have been affected by the flexure folding and other post-Deccan Trappean tectonic disturbances. Physiographically, the area is remarkably flat forming a narrow strip of coastal land where the climate is characterized by mean annual rainfall of about $3000 \mathrm{~mm}$, hot weather in summer (March to May), and high humidity throughout the year. In May (the hottest month of the year), the daily mean maximum temperature is $31.7^{\circ} \mathrm{C}$ and the daily mean minimum temperature is $26.4^{\circ} \mathrm{C}$. As this area experiences relatively high rainfall characteristic of a humid climate, the basaltic flows here are subjected to intensive weathering as evidenced by the presence of bauxitic and lateritic rocks carrying the signatures of intensive chemical leaching. Towards the east of Shrivardhan (on the way to Mumbai-Goa highway, near Sai village, figure 1) a red bole horizon (figure 2) is seen exposed between two basaltic flows. Both overlying and underlying basalts are extensively weathered as in other part of Deccan Traps basalts intercalating the bole beds are relatively fresh. In order to examine the use of flood basalt intercalated bole beds as palaeoclimatic proxy the whole section was studied and the results are presented.

\section{Methods of study}

The bole beds and the weathered basalt samples were crushed and powdered to analyze their major element compositions using X-ray fluorescence (Balaram et al. 1999). The crystal lattice water $\left(\mathrm{H}_{2} \mathrm{O}^{+}\right)$was determined by heating the rock samples at $600^{\circ} \mathrm{C}$ in an oven for about six hours. The major elemental analysis data are presented as weight percent oxides. Certain physical and chemical parameters like sodium adsorption ratio (SAR), 


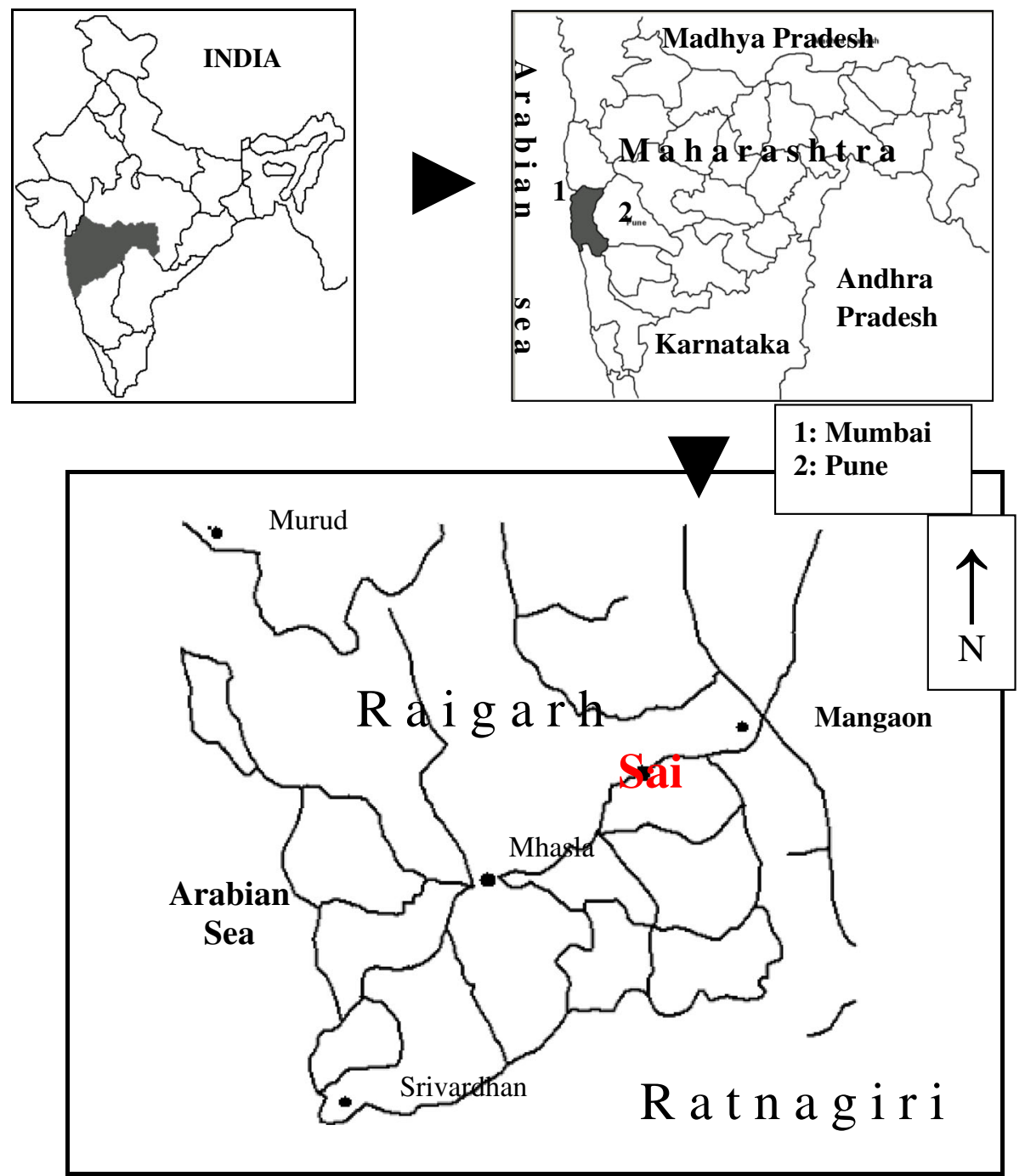

Figure 1. Location map of the study area.

cation exchange capacity (CEC), and organic carbon (OC) were estimated for bole beds and weathered basalts using the procedures given by Trivedi et al. (1987). The SAR, CEC, and OC may provide information about the nature of the environment with respect to chemical and biological activity. To understand the palaeoweathering of the bole beds and present day weathering of overlying and underlying basalts, various weathering indices were calculated. These indices were calculated from the molecular percent data (recalculated from weight percent data) since the stoichiometric proportions of various elements are commonly more informative in weathering studies than the weight percentages (Reiche 1943). The geochemistry of Sai bole beds was compared with the bole beds occurring elsewhere in the mainland of the Deccan traps (table 2). The rare earth elements analysis is presented in table 3.

\section{Results}

Red bole samples show CEC higher than the underlying and overlying weathered basalts (table 1; figure 3a) and the SAR and $\mathrm{OC}$ values are more for weathered basalts (figure $3 \mathrm{~b}$ and c). CEC depends upon the amount and type of clay and organic matter present in the soil; clay rich soils with more organic matter usually have higher CEC. Figure 3(a) suggests that the red bole samples from both the profiles are clay rich and show higher CEC values than the weathered basalts. SAR shows the relative proportion of $\mathrm{Na}^{+}$ions as compared to $\mathrm{Ca}^{++}$and $\mathrm{Mg}^{++}$ions. Figure 3(b) indicates that the bole beds have lesser amount of exchangeable sodium (lower SAR) in contrast to the weathered basalts. The $\mathrm{Al}_{2} \mathrm{O}_{3}, \quad \mathrm{TiO}_{2}$, and $\mathrm{Fe}_{2} \mathrm{O}_{3}(\mathrm{~T})$ values are lower in red boles than in the weathered basalts (figure $4 \mathrm{a}, \mathrm{b}$ and $\mathrm{c}$ ). Chemical index of alteration 
a: Profile 1

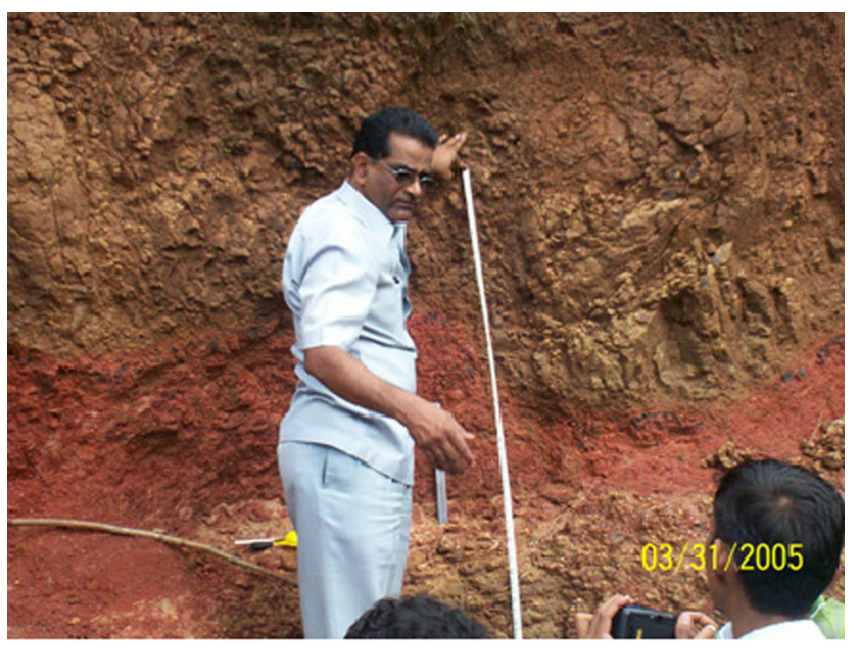

b: Profile 2

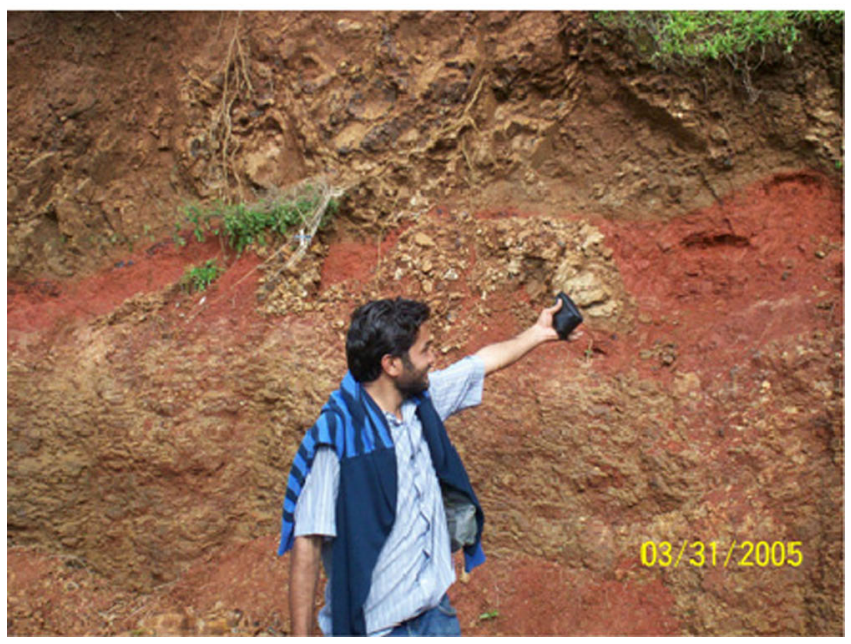

Figure 2. An intrabasaltic red bole horizon showing weathered overlying and underlying basalts.

(CIA) values (Nesbitt and Young 1982) and statistical empirical index of chemical weathering (W) values (Ohta and Arai 2007, figure 5a and b) are lower for red boles than the weathered basalts. The red boles also indicate more retention of original felsic and mafic components (figure $5 \mathrm{c}$ and d). Amongst alkali and alkaline earth metal oxides (figure $6 \mathrm{a}, \mathrm{b}$ and c) $\mathrm{K}_{2} \mathrm{O}$ shows erratic distribution and $\mathrm{MgO}$ and $\mathrm{CaO}$ are extensively leached from the weathered basalts. In the $\mathrm{SiO}_{2}-\mathrm{Al}_{2} \mathrm{O}_{3}-$ $\mathrm{Fe}_{2} \mathrm{O}_{3}$ triangular diagramme (Schellmann 1986) (figure 7) it is evident that the red boles are least weathered (close to basalt) and the overlying basalts are most weathered (highly kaolinized). Retallack (2003) devised measures to reflect hydrolysis $\left[\mathrm{Al}_{2} \mathrm{O} 3 /\left(\mathrm{CaO}+\mathrm{MgO}+\mathrm{Na}_{2} \mathrm{O}+\mathrm{K}_{2} \mathrm{O}\right)\right]$, calcification $\left[(\mathrm{CaO}+\mathrm{MgO}) / \mathrm{Al}_{2} \mathrm{O}_{3}\right]$, and salinization $\left(\mathrm{Na}_{2} \mathrm{O} / \mathrm{K}_{2} \mathrm{O}\right)$ with the advantages of their simplicity and precision, free from assumptions concerning parent material composition, and changes in volume during weathering and burial compaction. The computation of these indices shows that red boles show higher calcification (lesser leaching) and lower salinization (figure 8a and b) as compared to the associated basalts. The values of mean annual precipitation (MAP) and mean annual temperature (MAT) have been calculated by the formulae given by Sheldon et al. (2002) which are as follows:

$$
\operatorname{MAP}(\mathrm{mm})=-259.34 \ln (B)+759.05
$$

where $B=$ molar ratio of bases to alumina

$$
\operatorname{MAT}\left({ }^{\circ} \mathrm{C}\right)=-18.516(S)+17.298
$$

where $S=$ molecular ratio of $\mathrm{Na}_{2} \mathrm{O}$ and $\mathrm{K}_{2} \mathrm{O}$ to $\mathrm{Al}_{2} \mathrm{O}_{3}$.

\section{Discussion}

The emplacement of Deccan Trap lava flows was not a continuous process and the volcanic quiescence periods have been recorded by many intrabasaltic weathering and sedimentary horizons including the bole beds which are generally less than one meter thick. Bole beds bear witness to the processes occurring between emplacements of two successive lava flows and hence they can be effectively used to constrain the time intervals between the successive lava flows in the Deccan traps (Gerard et al. 2006). The red boles in the Deccan basalts, characteristically formed during the quiescence period of the fissure eruptions, have been considered as palaeosols as the palaeoweathering characters of the bole beds indicate that they are the weathered products of the parent basalts (Wilkins et al. 1994; Widdowson et al. 1997). Ghosh et al. (2006) and Sayyed and Hundekari (2006) in their recent studies concluded that Deccan bole beds are the paleosols which are formed by the pedogenesis of the underlying lava flows. In the mainland of Deccan Volcanic Province, generally the bole beds are sandwiched between only slightly weathered lower basalts and almost fresh, unweathered upper basalts. Thus, the bole beds are definitely the weathered products of the basalts and hence indicate the palaeoenvironment of their formation. In the study area, it was found that even the upper basalt along with lower basalt has been extensively weathered. The physico-chemical and geochemical characteristics of red bole horizons (figure 2) demonstrate that the red boles are conspicuously distinct from the underlying and overlying weathered basalts. The higher values of $\mathrm{Al}_{2} \mathrm{O}_{3}, \mathrm{TiO}_{2}, \mathrm{Fe}_{2} \mathrm{O}_{3}(\mathrm{~T})$, CIA, and $\mathrm{W}$ indicate that the basalts are more weathered than the red boles. Higher retention of felsic and mafic components of the original basalt; 
Table 1. Composition and selected parameters of the red boles and associated basalts.

\begin{tabular}{|c|c|c|c|c|c|c|c|c|c|c|}
\hline & \multicolumn{5}{|c|}{ Profile 1} & \multicolumn{5}{|c|}{ Profile 2} \\
\hline & $\overline{\mathrm{UB} 1}$ & RB1 & RB2 & RB3 & LB1 & $\overline{\mathrm{UB} 2}$ & RB4 & RB5 & RB6 & LB2 \\
\hline Depth (m) & 0.70 & 0.90 & 1.11 & 1.40 & 1.60 & 0.45 & 0.67 & 0.84 & 1.07 & 1.22 \\
\hline $\mathrm{SiO}_{2}$ & 36.25 & 43.48 & 43.35 & 43.71 & 41.04 & 37.60 & 44.79 & 43.98 & 43.80 & 40.25 \\
\hline $\mathrm{TiO}_{2}$ & 2.90 & 2.14 & 2.09 & 2.09 & 2.43 & 2.77 & 2.07 & 2.09 & 2.10 & 2.51 \\
\hline $\mathrm{Al}_{2} \mathrm{O}_{3}$ & 17.08 & 12.81 & 12.88 & 12.13 & 15.41 & 18.16 & 12.48 & 12.33 & 12.11 & 16.49 \\
\hline $\mathrm{Fe}_{2} \mathrm{O}_{3}$ & 21.55 & 17.41 & 17.28 & 17.33 & 18.90 & 19.97 & 17.25 & 17.09 & 17.63 & 17.31 \\
\hline $\mathrm{MgO}$ & 3.11 & 4.86 & 4.96 & 4.71 & 4.18 & 3.04 & 4.88 & 5.24 & 4.89 & 4.07 \\
\hline $\mathrm{CaO}$ & 0.77 & 1.54 & 1.51 & 1.48 & 1.23 & 0.77 & 1.55 & 1.64 & 1.55 & 1.12 \\
\hline $\mathrm{Na}_{2} \mathrm{O}$ & 0.0008 & 0.0008 & 0.0008 & 0.0008 & 0.0009 & 0.0008 & 0.0009 & 0.0008 & 0.0008 & 0.0008 \\
\hline $\mathrm{K}_{2} \mathrm{O}$ & 0.12 & 0.40 & 0.32 & 0.68 & 0.32 & 0.09 & 0.15 & 0.19 & 0.63 & 0.19 \\
\hline $\mathrm{H}_{2} \mathrm{O}^{+}$ & 17.97 & 17.15 & 17.56 & 17.83 & 16.46 & 17.56 & 16.81 & 17.42 & 17.01 & 17.83 \\
\hline Total & 99.75 & 99.79 & 99.95 & 99.96 & 99.97 & 99.96 & 99.98 & 99.98 & 99.72 & 99.77 \\
\hline Salinization & 0.0071 & 0.0021 & 0.0026 & 0.0012 & 0.0027 & 0.0091 & 0.0056 & 0.0043 & 0.0013 & 0.0045 \\
\hline Calcification & 0.23 & 0.50 & 0.50 & 0.51 & 0.35 & 0.21 & 0.51 & 0.56 & 0.53 & 0.31 \\
\hline Mafic components & 3.28 & 4.46 & 4.73 & 3.68 & 3.66 & 3.35 & 6.20 & 6.20 & 3.96 & 3.91 \\
\hline Felsic components & 0.00 & 0.01 & 0.01 & 0.02 & 0.01 & 0.00 & 0.01 & 0.01 & 0.02 & 0.01 \\
\hline W & 84.98 & 53.87 & 54.23 & 54.37 & 64.35 & 84.89 & 52.77 & 51.31 & 53.22 & 67.48 \\
\hline CIA & 95.04 & 86.80 & 87.50 & 84.88 & 90.88 & 95.48 & 88.02 & 87.03 & 84.75 & 92.65 \\
\hline Organic carbon & 4.42 & 3.56 & 2.10 & 3.39 & 3.61 & 5.81 & 4.32 & 2.46 & 1.65 & 4.35 \\
\hline $\mathrm{CEC}$ & 80.90 & 208.05 & 189.80 & 175.70 & 130.30 & 61.80 & 208.80 & 201.15 & 172.30 & 105.60 \\
\hline SAR & 0.40 & 0.25 & 0.26 & 0.20 & 0.24 & 0.46 & 0.26 & 0.19 & 0.26 & 0.35 \\
\hline
\end{tabular}

UB: Upper basalt; RB: Red bole; LB: Lower basalt.

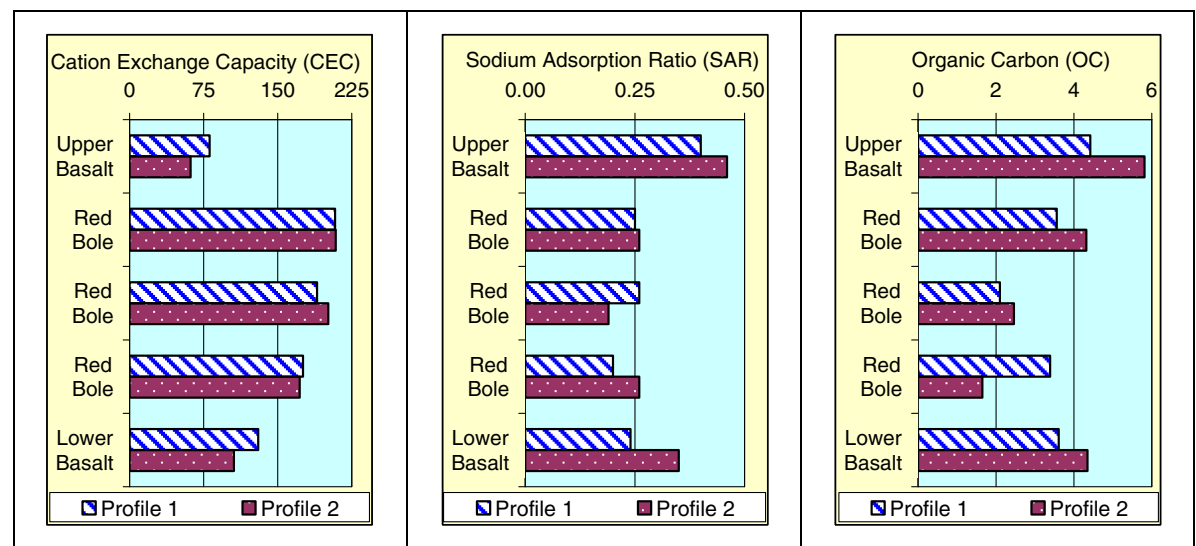

Figure 3. Variations of cation exchange capacity, sodium adsorption ratio and organic carbon.

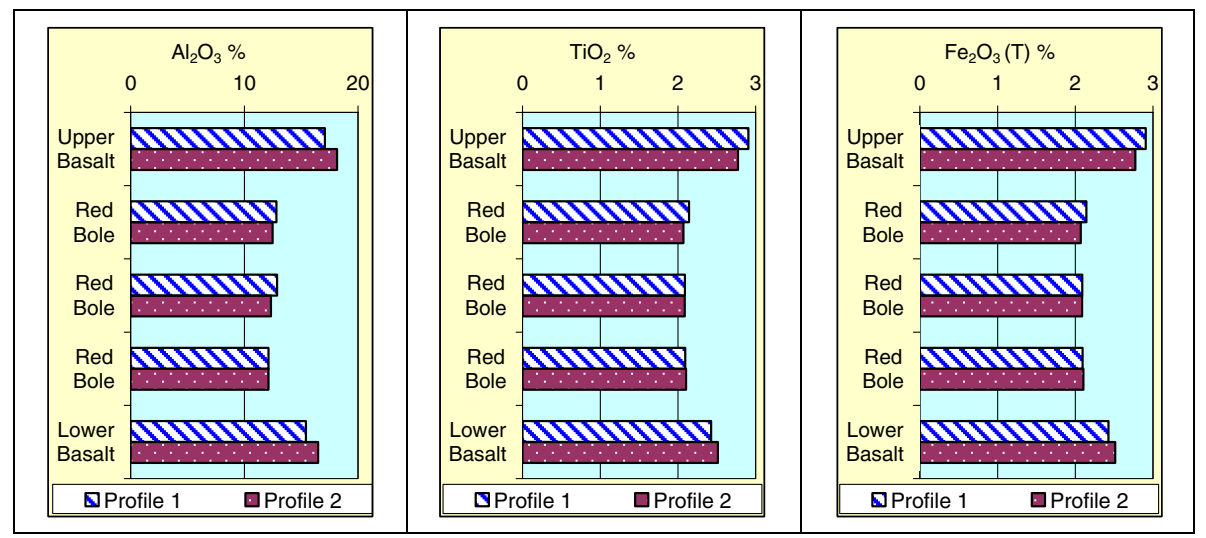

Figure 4. Variations of $\mathrm{Al}_{2} \mathrm{O}_{3}, \mathrm{TiO}_{2}$ and $\mathrm{Fe}_{2} \mathrm{O}_{3}(\mathrm{~T})$. 


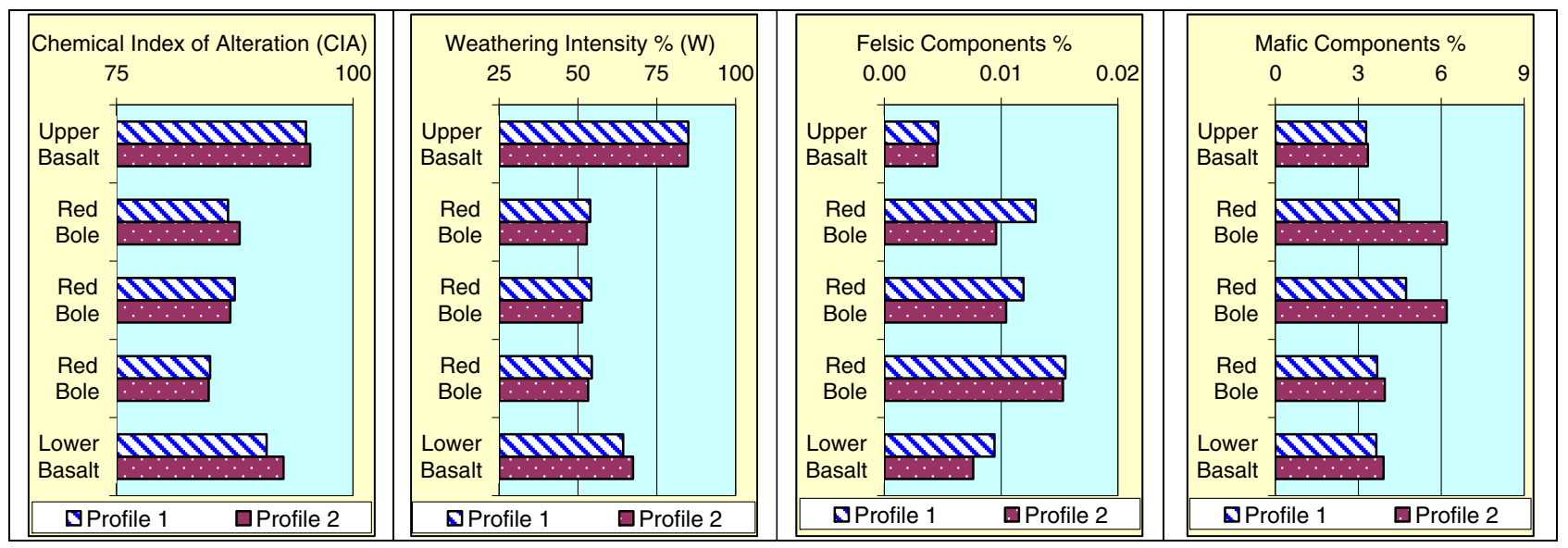

Figure 5. Variations of chemical index of alteration (CIA), empirical statistical index of weathering (W), felsic components and mafic components.

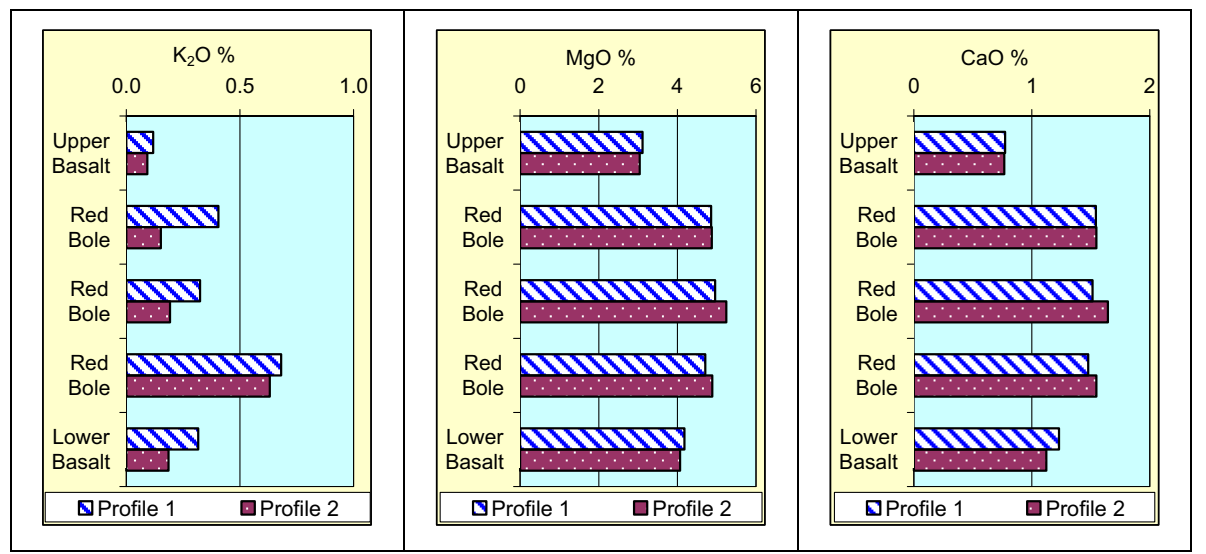

Figure 6. Variations of $\mathrm{K}_{2} \mathrm{O}, \mathrm{MgO}$ and $\mathrm{CaO}$.

higher concentration of $\mathrm{CaO}$ and $\mathrm{MgO}$; and higher calcification and lower salinization in the red bole samples further support the theory that the red boles are less weathered. The $\mathrm{SiO}_{2}-\mathrm{Al}_{2} \mathrm{O}_{3}-\mathrm{Fe}_{2} \mathrm{O}_{3}$ (figure 7) plot also clearly shows that the red boles are least weathered as compared to the upper basalts. The REE studies suggest that the red boles were not recycled and they are in-situ products of basalt weathering.

The geochemical comparison of the Sai red boles with those occurring in the mainland of Deccan Traps has been attempted (table 2) to constrain the effects of post-formational processes on the bole beds. Deccan Trap bole beds are the weathering products of the basalts and hence they show higher weathering characteristics than the parent underlying (weathered) basalts. At the same time the overlying basalts are quite fresh and relatively unaltered which clearly indicates fairly good preservation of the bole beds from the postformational processes like weathering, digenesis, or metasomatism. When the Sai red boles are compared with other Deccan Trappean bole beds with

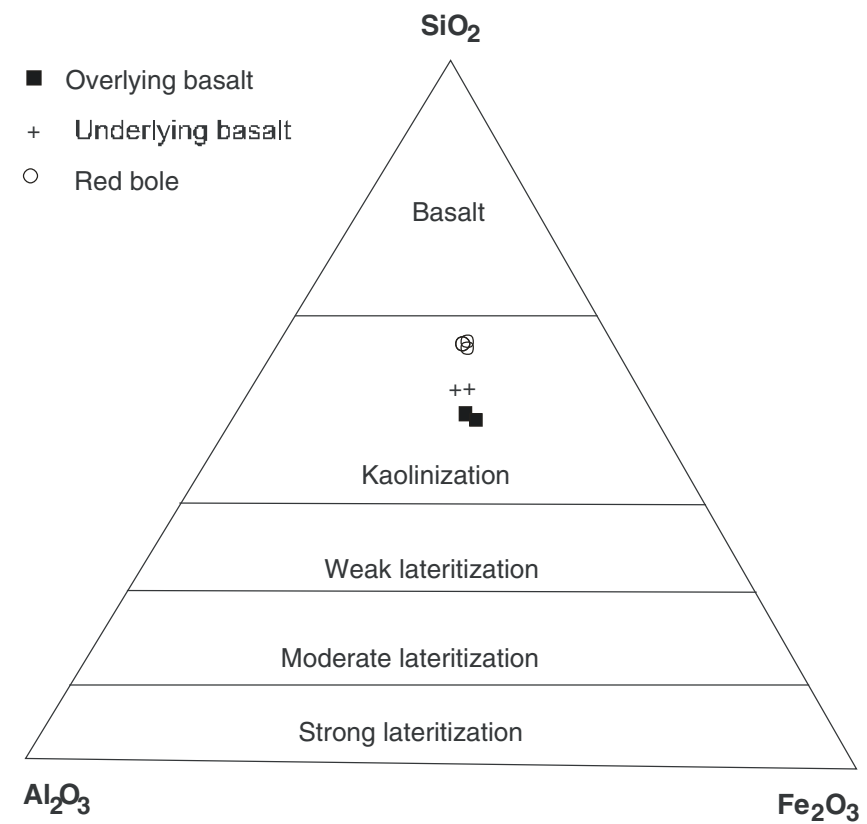

Figure 7. $\mathrm{SiO}_{2}-\mathrm{Al}_{2} \mathrm{O}_{3}-\mathrm{Fe}_{2} \mathrm{O}_{3}$ triangular plot indicating extent of lateritization (after Schellmann 1986). 
the help of geochemistry it was found that Sai red boles show higher hydrolysis and lower calcification (figure 9a); extensive leaching of bases (figure 9b); and considerably higher weathering intensity (figure 9c) than other Deccan bole beds. Further, the mean annual precipitation (MAP) values for Sai red boles are lower (figure 9d) with higher mean annual temperature (MAT) values than other Deccan boles. All these observations indicate that the Sai red boles have been more altered than the rest

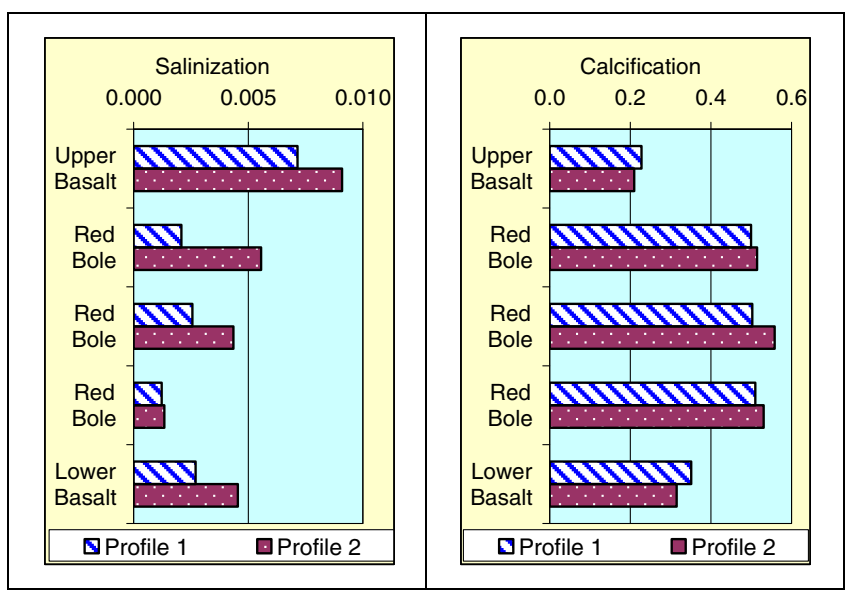

Figure 8. Variations of calcification and salinization. of the bole beds, which can be ascribed to the postformational processes, especially chemical weathering and leaching of bases. However, it is also evident (figure 5) that the lower and upper basalts from Sai have been quite extensively weathered as compared to the Sai red boles which is unusual, as other Deccan Trappean bole beds invariably show higher weathering characteristics than the associated basalts. Further, it is also evident that Sai upper basalts show extensive weathering (higher than lower basalt) which is also unusual as compared to other Deccan upper basalts. Hence, it can be said that the whole red bole profile (including associated basalts) from Sai has been affected by post-formational processes. However, the red boles have been least affected while associated basalts (especially upper basalt) were undergoing significant and rather extensive chemical weathering during the Holocene.

From the extensive studies on the behaviour of rare earth elements (REEs) during weathering (see Laveuf and Cornu 2009 and references therein), it has been found that the REE stock generally decreases with an increase in weathering. The upper part of weathering profiles show general depletion of REEs and the bottom part of the profile may, some times, get enriched with REEs possibly due to their reprecipitation (Braun et al.

Table 2. Molecular weight percent data for the bole beds and the associated basalts.

\begin{tabular}{|c|c|c|c|c|c|c|c|c|c|c|c|c|c|c|c|}
\hline & \multicolumn{5}{|c|}{ Deccan bole beds } & \multicolumn{6}{|c|}{ Sai red boles } & \multicolumn{2}{|c|}{$\begin{array}{c}\text { Sai lower } \\
\text { basalt }\end{array}$} & \multicolumn{2}{|c|}{$\begin{array}{c}\text { Sai upper } \\
\text { basalt }\end{array}$} \\
\hline & $\#$ & $\#$ & $\$$ & $\mu$ & $\S$ & & & & & resent & study & & & & \\
\hline & $\mathrm{PRB}$ & PGB & $\mathrm{ARB}$ & SGD & IB & RB1 & RB2 & RB3 & $\mathrm{RB} 4$ & RB5 & $\mathrm{RB} 6$ & LB1 & LB2 & UB1 & $\mathrm{UB} 2$ \\
\hline $\mathrm{SiO}_{2}$ & 49.31 & 55.67 & 42.40 & 43.21 & 43.86 & 43.68 & 43.40 & 43.75 & 44.82 & 43.98 & 44.08 & 41.08 & 40.49 & 36.50 & 37.64 \\
\hline $\mathrm{TiO}_{2}$ & 2.31 & 1.88 & 2.23 & 2.12 & 1.97 & 2.14 & 2.09 & 2.09 & 2.07 & 2.09 & 2.10 & 2.43 & 2.51 & 2.90 & 2.77 \\
\hline $\mathrm{Al}_{2} \mathrm{O}_{3}$ & 12.16 & 10.07 & 13.97 & 13.03 & 12.07 & 12.81 & 12.88 & 12.13 & 12.48 & 12.33 & 12.11 & 15.41 & 16.49 & 17.08 & 18.16 \\
\hline $\mathrm{Fe}_{2} \mathrm{O}_{3}(\mathrm{~T})$ & 18.11 & 15.11 & 14.66 & 15.61 & 15.11 & 17.41 & 17.28 & 17.33 & 17.25 & 17.09 & 17.63 & 18.90 & 17.31 & 21.55 & 19.97 \\
\hline $\mathrm{MgO}$ & 4.95 & 5.64 & 4.05 & 4.67 & 4.57 & 4.86 & 4.96 & 4.71 & 4.88 & 5.24 & 4.89 & 4.18 & 4.07 & 3.11 & 3.04 \\
\hline $\mathrm{CaO}$ & 2.74 & 2.42 & 4.98 & 4.58 & 4.18 & 1.54 & 1.51 & 1.48 & 1.55 & 1.64 & 1.55 & 1.23 & 1.12 & 0.77 & 0.77 \\
\hline $\mathrm{Na}_{2} \mathrm{O}$ & 0.09 & 0.06 & 0.54 & 0.39 & 0.33 & 0.001 & 0.001 & 0.001 & 0.001 & 0.001 & 0.001 & 0.001 & 0.001 & 0.001 & 0.001 \\
\hline $\mathrm{K}_{2} \mathrm{O}$ & 0.68 & 1.76 & 1.75 & 0.46 & 0.45 & 0.40 & 0.32 & 0.68 & 0.15 & 0.19 & 0.63 & 0.32 & 0.19 & 0.12 & 0.09 \\
\hline $\mathrm{H}_{2} \mathrm{O}^{+}$ & 9.37 & 7.12 & 15.03 & 15.67 & 16.55 & 17.15 & 17.56 & 17.83 & 16.81 & 17.42 & 17.01 & 16.46 & 17.83 & 17.97 & 17.56 \\
\hline Total & 99.72 & 99.73 & 99.61 & 99.74 & 99.09 & 100 & 100 & 100 & 100 & 100 & 100 & 100 & 100 & 100 & 100 \\
\hline CIA & 67.41 & 61.05 & 54.09 & 57.92 & 58.27 & 86.80 & 87.50 & 84.88 & 88.02 & 87.03 & 84.75 & 90.88 & 92.65 & 95.04 & 95.48 \\
\hline Bases $/ \mathrm{R}_{2} \mathrm{O}_{3}$ & 0.69 & 0.94 & 0.85 & 0.83 & 0.84 & 0.59 & 0.59 & 0.60 & 0.59 & 0.64 & 0.61 & 0.43 & 0.41 & 0.27 & 0.27 \\
\hline $\mathrm{SiO}_{2} / \mathrm{R}_{2} \mathrm{O}_{3}$ & 3.15 & 4.28 & 2.76 & 2.86 & 3.08 & 2.79 & 2.78 & 2.88 & 2.92 & 2.89 & 2.88 & 2.29 & 2.24 & 1.80 & 1.86 \\
\hline Hydrolysis & 0.66 & 0.48 & 0.63 & 0.61 & 0.59 & 0.82 & 0.82 & 0.79 & 0.81 & 0.74 & 0.76 & 1.16 & 1.31 & 1.80 & 1.96 \\
\hline Calcification & 1.45 & 1.87 & 1.39 & 1.55 & 1.60 & 1.19 & 1.20 & 1.21 & 1.22 & 1.33 & 1.26 & 0.84 & 0.75 & 0.55 & 0.50 \\
\hline Salinization & 0.20 & 0.05 & 0.47 & 1.30 & 1.11 & 0.00 & 0.00 & 0.00 & 0.01 & 0.01 & 0.00 & 0.00 & 0.01 & 0.01 & 0.01 \\
\hline Product index & 75.88 & 81.07 & 73.37 & 74.10 & 75.49 & 73.60 & 73.53 & 74.21 & 74.47 & 74.28 & 74.22 & 69.56 & 69.14 & 64.25 & 65.02 \\
\hline MAP & 880 & 914 & 884 & 888 & 894 & 811 & 812 & 822 & 814 & 836 & 831 & - & - & - & - \\
\hline MAT & 15.74 & 14.44 & 13.57 & 15.68 & 15.72 & 16.66 & 16.79 & 16.17 & 17.05 & 16.98 & 16.25 & - & - & - & - \\
\hline
\end{tabular}

\# Sayyed and Hundeksri (2006) and Ghosh et al. (2006); ${ }^{\$}$ Inamdar and Darshan Kumar (1994); ${ }^{\mu}$ Widdowson et al. (1997); ${ }^{\S}$ Wilkins et al. (1994). PRB (Pune Red Boles); PGB (Pune Green Boles); ARB (Akola Red Boles); SGD (Sinhgad Red Boles); IB (Average Indian Boles). 
Table 2. (Continued.)

\begin{tabular}{|c|c|c|c|c|c|c|c|c|c|c|c|c|c|}
\hline & \multicolumn{13}{|c|}{ Sayyed and Hundekari (2006) and Ghosh et al. (2006) } \\
\hline & \multicolumn{5}{|c|}{ Deccan lower basalts } & \multicolumn{8}{|c|}{ Deccan upper basalts } \\
\hline & $\mathrm{A} 2$ & F2 & G1 & $\mathrm{H} 2$ & $\mathrm{I} 2$ & A1 & B1 & D1 & E1 & F1 & G2 & H1 & $\mathrm{I} 1$ \\
\hline$\overline{\mathrm{SiO}_{2}}$ & 49.63 & 48.72 & 51.23 & 47.74 & 50.99 & 52.81 & 49.65 & 50.06 & 50.32 & 54.17 & 50.22 & 48.45 & 49.56 \\
\hline $\mathrm{TiO}_{2}$ & 3.24 & 3.97 & 2.54 & 3.45 & 2.44 & 2.29 & 2.16 & 2.1 & 2.92 & 2.19 & 1.96 & 3.24 & 2.02 \\
\hline $\mathrm{Al}_{2} \mathrm{O}_{3}$ & 11.22 & 12.2 & 14.67 & 14.14 & 12.87 & 16.96 & 13.83 & 13.44 & 12.87 & 15.84 & 15.2 & 15.14 & 14.07 \\
\hline $\mathrm{Fe}_{2} \mathrm{O}_{3}(\mathrm{~T})$ & 16.91 & 15.75 & 14.70 & 19.09 & 14.49 & 8.04 & 12.42 & 15.12 & 15.91 & 10.51 & 14.22 & 16.84 & 13.73 \\
\hline $\mathrm{MgO}$ & 5.6 & 5.27 & 4.79 & 5.11 & 6.39 & 4.52 & 7.22 & 5.73 & 5.29 & 5.18 & 5.58 & 4.76 & 6.25 \\
\hline $\mathrm{CaO}$ & 7.34 & 5.88 & 6.69 & 3.34 & 10.11 & 5.7 & 9.17 & 10.51 & 9.86 & 7.5 & 9.77 & 6.07 & 11.33 \\
\hline $\mathrm{Na}_{2} \mathrm{O}$ & 1.38 & 1.36 & 1.4 & 0.42 & 1.64 & 1.84 & 1.64 & 2.25 & 2.29 & 1.94 & 1.9 & 1.17 & 2.1 \\
\hline $\mathrm{K}_{2} \mathrm{O}$ & 0.71 & 0.93 & 1 & 0.19 & 0.27 & 3.88 & 0.3 & 0.25 & 0.27 & 1.75 & 0.53 & 0.22 & 0.39 \\
\hline $\mathrm{H}_{2} \mathrm{O}^{+}$ & 3.5 & 5.81 & 3.38 & 6.28 & 0 & 3.55 & 3.13 & 1.23 & 0.52 & 1.07 & 1.08 & 2.89 & 0.56 \\
\hline Total & 99.62 & 100.32 & 100.63 & 99.88 & 99.46 & 99.85 & 99.61 & 100.28 & 100.12 & 100.29 & 100.25 & 99.14 & 100.08 \\
\hline CIA & 40.61 & 46.64 & 48.51 & 66.95 & 37.55 & 49.05 & 41.21 & 36.77 & 36.89 & 45.79 & 41.42 & 53.39 & 36.47 \\
\hline Bases $/ \mathrm{R}_{2} \mathrm{O}_{3}$ & 1.17 & 1.00 & 1.02 & 0.65 & 1.49 & 1.17 & 1.56 & 1.46 & 1.33 & 1.26 & 1.33 & 0.85 & 1.59 \\
\hline $\mathrm{SiO}_{2} / \mathrm{R}_{2} \mathrm{O}_{3}$ & 3.23 & 3.03 & 3.19 & 2.64 & 3.44 & 3.59 & 3.45 & 3.30 & 3.20 & 3.64 & 3.19 & 2.74 & 3.32 \\
\hline Hydrolysis & 0.37 & 0.45 & 0.53 & 0.71 & 0.34 & 0.58 & 0.36 & 0.36 & 0.36 & 0.50 & 0.43 & 0.60 & 0.35 \\
\hline Calcification & 2.46 & 1.98 & 1.66 & 1.35 & 2.70 & 1.29 & 2.54 & 2.51 & 2.44 & 1.70 & 2.11 & 1.53 & 2.60 \\
\hline Salinization & 2.95 & 2.22 & 2.12 & 3.35 & 9.21 & 0.72 & 8.29 & 13.65 & 12.86 & 1.68 & 5.44 & 8.06 & 8.16 \\
\hline Product index & 76.35 & 75.21 & 76.15 & 72.55 & 77.46 & 78.21 & 77.50 & 76.76 & 76.19 & 78.43 & 76.13 & 73.30 & 76.83 \\
\hline
\end{tabular}

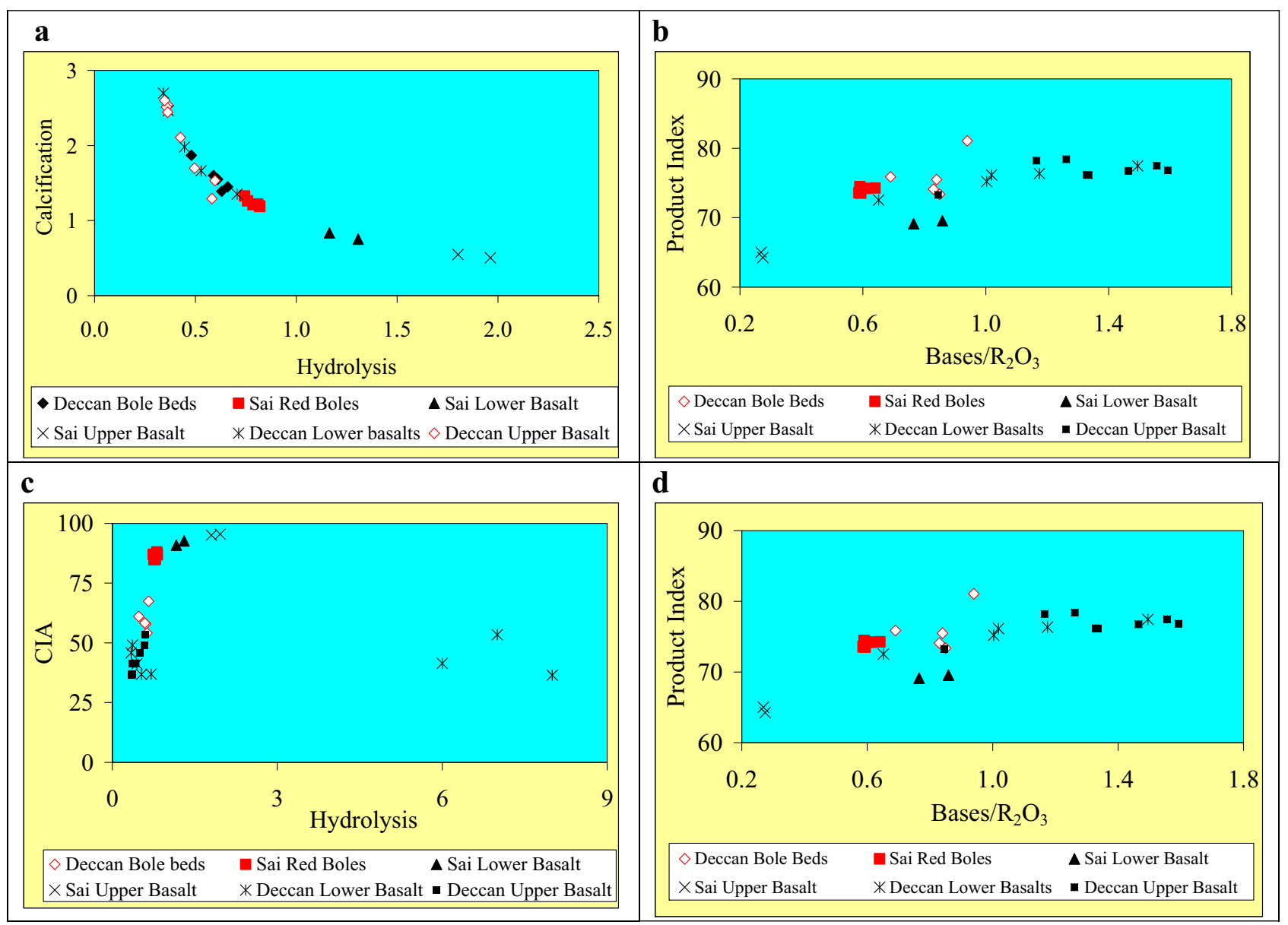

Figure 9. Comparison of Sai red boles and associated basalts with other Deccan bole beds and basalts. 
Table 3. Chondrite normalized REE concentrations (ppm) for the bole beds and the associated basalts.

\begin{tabular}{|c|c|c|c|c|c|c|c|c|c|c|}
\hline & \multicolumn{5}{|c|}{ Profile 1} & \multicolumn{5}{|c|}{ Profile 2} \\
\hline & $\overline{\mathrm{UB} 1}$ & RB1 & RB2 & RB3 & LB1 & $\overline{\mathrm{UB} 2}$ & RB4 & RB5 & RB6 & $\overline{\mathrm{LB} 2}$ \\
\hline $\mathrm{La}$ & 72.4 & 229.8 & 254.8 & 222.4 & 97.4 & 78.1 & 75.96 & 100.3 & 158.5 & 223.6 \\
\hline $\mathrm{Ce}$ & 57.7 & 179.1 & 205.5 & 179.4 & 76.3 & 65.2 & 55.6 & 73.48 & 127.8 & 189.8 \\
\hline $\mathrm{Pr}$ & 52.4 & 136.8 & 134.5 & 117.9 & 61.74 & 53.75 & 54.48 & 71.91 & 89.76 & 97.75 \\
\hline $\mathrm{Nd}$ & 44.36 & 95.42 & 86.22 & 78.83 & 51.27 & 42.42 & 46.29 & 60.81 & 64.8 & 51.08 \\
\hline $\mathrm{Sm}$ & 35.52 & 45.52 & 51.82 & 48.51 & 35.78 & 35.84 & 30.65 & 43.7 & 39.48 & 32.47 \\
\hline $\mathrm{Eu}$ & 28.78 & 36.71 & 40.16 & 40.16 & 27.92 & 29.3 & 23.44 & 40.85 & 33.09 & 25.68 \\
\hline $\mathrm{Gd}$ & 25.94 & 34.65 & 43.76 & 37.49 & 27.02 & 25.26 & 25.89 & 31.03 & 31.47 & 25.8 \\
\hline $\mathrm{Tb}$ & 24.03 & 29.37 & 38.72 & 32.58 & 24.3 & 23.23 & 23.23 & 28.84 & 28.04 & 21.9 \\
\hline Dy & 22.12 & 22.71 & 35.58 & 30.42 & 21.84 & 21.33 & 21.96 & 27.39 & 25.38 & 19.4 \\
\hline Ho & 21.69 & 20.46 & 33.33 & 28.04 & 20.99 & 20.46 & 20.81 & 24.69 & 23.46 & 18.17 \\
\hline Er & 18.49 & 17.41 & 27.95 & 23.86 & 17.71 & 17.41 & 17.47 & 22.29 & 19.88 & 17.05 \\
\hline $\mathrm{Tm}$ & 17.57 & 16.4 & 26.94 & 22.26 & 16.01 & 16.4 & 17.18 & 21.09 & 19.52 & 14.45 \\
\hline $\mathrm{Yb}$ & 18.66 & 17.5 & 27.14 & 22.29 & 16.9 & 17.14 & 17.26 & 21.2 & 18.23 & 14.17 \\
\hline $\mathrm{Lu}$ & 17.72 & 18.12 & 24.81 & 21.27 & 15.75 & 17.72 & 16.94 & 19.69 & 17.72 & 14.97 \\
\hline LREE & 291.3 & 723.3 & 773 & 687.2 & 350.4 & 304.6 & 286.4 & 391 & 513.4 & 620.4 \\
\hline HREE & 166.2 & 176.6 & 258.2 & 218.2 & 160.5 & 159 & 160.7 & 196.2 & 183.7 & 145.9 \\
\hline REE & 457.5 & 900 & 1031 & 905.4 & 510.9 & 463.5 & 447.2 & 587.2 & 697.2 & 766.3 \\
\hline$(\mathrm{La} / \mathrm{Yb})_{\mathrm{N}}$ & 3.88 & 13.12 & 9.39 & 9.978 & 5.76 & 4.55 & 4.4 & 4.73 & 8.69 & 15.77 \\
\hline$(\mathrm{La} / \mathrm{Lu})_{\mathrm{N}}$ & 4.08 & 12.68 & 10.27 & 10.45 & 6.18 & 4.4 & 4.48 & 5.09 & 8.94 & 14.93 \\
\hline$(\mathrm{Gd} / \mathrm{Yb})_{\mathrm{N}}$ & 1.39 & 1.97 & 1.61 & 1.68 & 1.59 & 1.47 & 1.5 & 1.46 & 1.72 & 1.82 \\
\hline$(\mathrm{Eu} / \mathrm{Sm})_{\mathrm{N}}$ & 0.81 & 0.8 & 0.77 & 0.82 & 0.78 & 0.81 & 0.76 & 0.93 & 0.83 & 0.79 \\
\hline $\mathrm{Ce} / \mathrm{Ce}^{*}$ & 0.94 & 1.01 & 1.11 & 1.11 & 0.98 & 1.01 & 0.86 & 0.87 & 1.07 & 1.28 \\
\hline $\mathrm{Eu} / \mathrm{Eu}^{*}$ & 0.95 & 0.92 & 0.84 & 0.94 & 0.9 & 0.97 & 0.83 & 1.11 & 0.94 & 0.89 \\
\hline
\end{tabular}

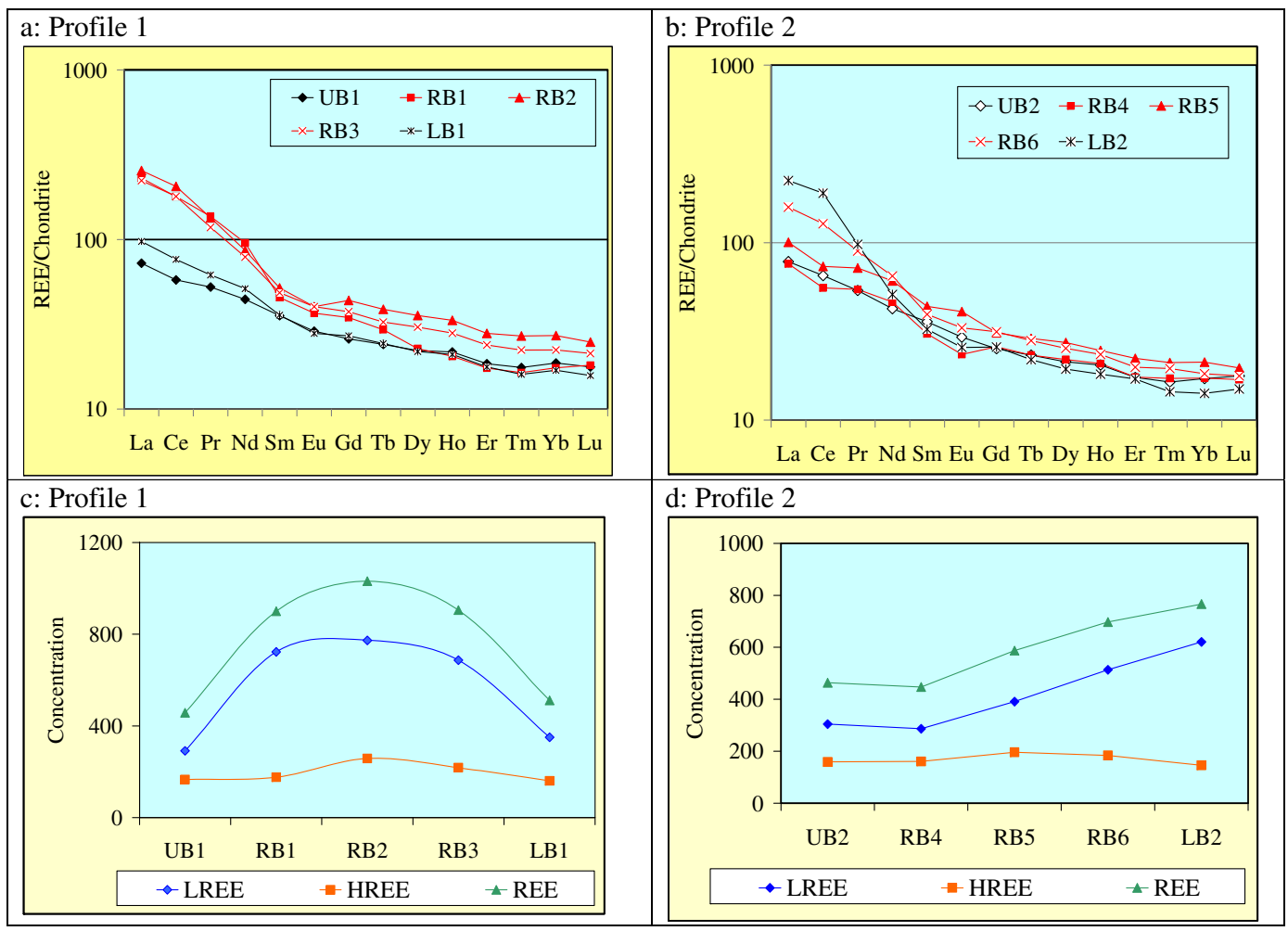

Figure 10. Distribution of rare earth elements in the Sai red boles and associated basalts. 
1993; Nesbitt and Markovics 1997; Ma et al. 2002). Although, in most cases, weathering results in a relative enrichment of LREEs over HREEs in the weathering profile (Nesbitt 1979; Duddy 1980; Topp et al. 1984; Braun et al. 1990; Boulange and Colin 1994; Compton et al. 2003), the LREEs accumulated during alkaline phases of weathering can be leached out in acidic environment (Ronov et al. 1967; Huang and Gong 2001). REE behaviour could trace weathering processes (Gnandi and Tobschall 2003) as weathering induces REE fractionation.

Chondrite normalized REE pattern of both the red boles profiles (table 3) indicate REE fractionation (figure 10a and b) wherein the weathered basalt shows more depletion than the red boles. The distribution pattern of REE, LREE and HREE in both the profiles (figure 10c and d) also indicate rather high depletion of REEs from the basalts, which supports the premise that the red boles escaped further weathering when the associated basalts were undergoing chemical alteration in the Holocene. $\mathrm{Eu} / \mathrm{Eu}^{*}$ versus $(\mathrm{Gd} / \mathrm{Yb})_{\mathrm{N}}$ plot (figure 11a and b) suggests that the red boles and associated basalts were affected by intracrustal differentiation as $\mathrm{Eu} / \mathrm{Eu}^{*}$ values are more than 0.85 .

\section{Profile 1}

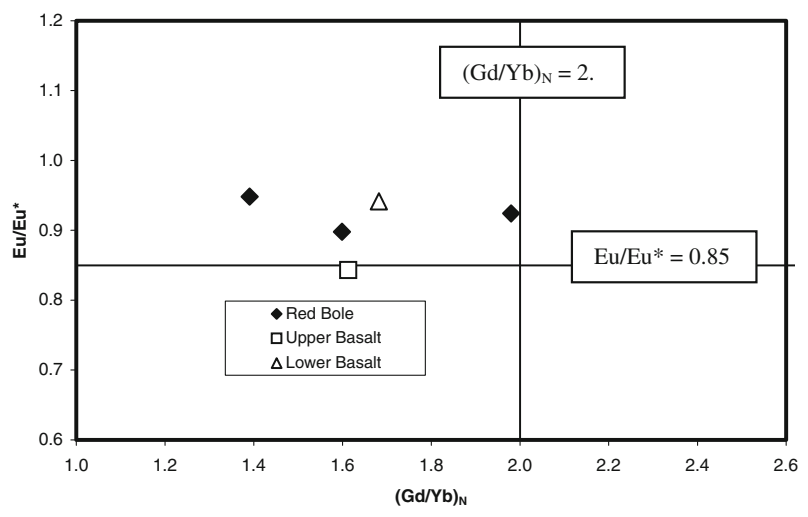

Profile 2

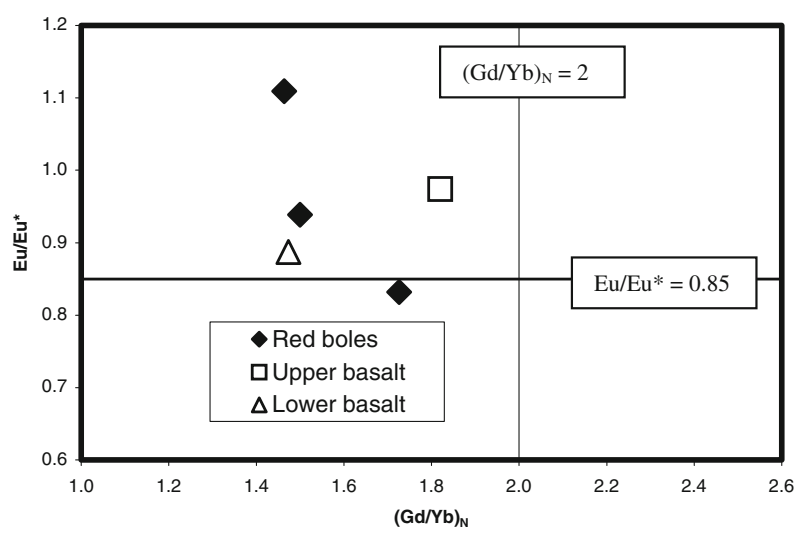

Figure 11. $(\mathrm{Gd} / \mathrm{Yb})_{\mathrm{N}}$ versus $\mathrm{Eu} / \mathrm{Eu}^{*}$ plot for Sai red boles and the weathered basalt.
Also $(\mathrm{Gd} / \mathrm{Yb})_{\mathrm{N}}$ values are less than 2.00, indicating that red boles were not recycled and they are in-situ products of basalt weathering.

\section{Conclusions}

The subaerial weathering of the parent basalts in most of the continental flood basalt provinces has resulted in a concomitant development of the palaeosols, representing the well-defined intereruptive time intervals. They are often sandwiched between the slightly weathered to fresh basalt flows, when compared in terms of the degree of weathering. Therefore, such intrabasaltic palaeosols are being used recently to constrain the palaeoweathering and palaeoclimates during these episodes (Widdowson et al. 1997; Hill et al. 2000; Sheldon 2002, 2003; Sheldon et al. 2002; SolleiroRebolledo et al. 2003; Tabor et al. 2004; Ghosh et al. 2006; Sayyed and Hundekari 2006; etc.) as climatic effects of the flood basalts are often considered to be severe. However, a fundamental question is whether such palaeosols can be reliably useful for palaeoenvironmental reconstructions or whether those have been altered by baking or metasomatism (Sheldon 2003). Studies on such palaeosols from different basaltic provinces have so far revealed vital climatic information. The earlier studies on Deccan bole beds suggested that $\mathrm{pH}$ during the bole bed formations could have been lower than 6 ; the weathering conditions were not as intensely oxidizing as in the modern soil formation on basalts (or the modern soils have been forming for much longer) and the absence of pedogenic carbonates in bole beds indicates they formed in a climate with precipitation greater than evaporation (Sayyed and Hundekari 2006). The stable isotopic analyses of clay minerals from bole beds indicate a highly depleted signature of meteoric water providing an evidence of enhanced precipitation or mega monsoonal circulation during the Late Cretaceous period (Ghosh et al. 2006). The Sai bole beds also seem to have been formed under similar conditions as seen from physico-chemical and geochemical comparisons as they are not affected much by leaching under present day higher rainfall. These are the signatures of the palaeoweathering conditions of their formation, which have been retained even as the associated basalts show higher intensity of weathering due to the present day higher rainfall. From the present study it is evident that the red bole has retained, to a considerable extent, its original weathering characteristics, as the overlying and underlying basalts have weathered (Holocene weathering) to far more extent indicating the present day weathering conditions. Hence, it can be concluded that the intrabasaltic 
palaeosols (bole beds) prove to be of great significance as a palaeoclimatic proxy because postformational processes like weathering, baking, digenesis, or metasomatism have least affected them as compared to the associated basalts which host them.

\section{References}

Agashe L V and Gupte R B 1968 Some significant features of Deccan Traps; Geol. Soc. India Memoir 2 309-311.

Balaram V, Gnaneswara Rao T and Anjaiah K V 1999 International proficiency tests for analytical geochemistry laboratories: An assessment of accuracy and precision in routine geochemical analysis; J. Geol. Soc. India $\mathbf{5 3}$ 417-423.

Boulange B and Colin F 1994 Rare earth element mobility during conversion of nepheline syenite into lateritic bauxite at Passa Quatro, Minais Gerais, Brazil; Appl. Geochem. 9 701-711.

Braun J-J, Pagel M, Muller J-P, Bilong P, Michard A and Guillet B 1990 Cerium anomalies in lateritic profiles; Geochim. Cosmochim. Acta 54 781-795.

Braun J-J, Pagel M, Herbillon A and Rosin C 1993 Mobilization and redistribution of REEs and Thorium in a syenitic lateritic profile - a mass-balance study; Geochim. Cosmochim. Acta $\mathbf{5 7}$ 4419-4434.

Coffin M F and Eldholm O 1994 Large igneous provinces: Crustal structure, dimensions and external consequences; Rev. Geophys. 32 1-36.

Compton J S, White R A and Smith M 2003 Rare earth element behavior in soils and salt pan sediments of a semiarid granitic terrain in the Western Cape, South Africa; Chem. Geol. 201 239-255.

Courtillot V 1990 Deccan Volcanism at the Cretaceous tertiary boundary: Past climate crises as a key to the future? Palaeogeogr. Palaeoclimatol. Paleoecol. 189 291299.

Courtillot V, Jaeger J J, Yang Z, Feraud G and Hofman C 1996 The influence of continental flood basalts on mass extinctions: Where do we stand? In: The CretaceousTertiary event and other catastrophes in earth history (eds) Ryder G, Fastovsky D and Gartner S, Geol. Soc. America, Spec. Paper 307 513-526.

Duddy L R 1980 Redistribution and fractionation of rareearth and other elements in a weathering profile; Chem. Geol. 30 363-381.

Fermor L L 1927 On the basaltic lava flows penetrated by deep boring for coal at Bhusawal, Bombay Presidency; Rec. Geol. Surv. India 58 95-240.

Gerard M, Caquineau S, Chenet A L, Fluteau F, Courtillot V and Subbarao K V 2006 Red boles in the Deccan traps: Time constraints from alteration processes; Geophys. Res. Abstr. 807092.

Ghosh Prosenjit, Sayyed M R G, Islam R and Hundekari S M 2006 Inter-basaltic clay (bole bed) horizons from Deccan traps of India: Implications for palaeo-weathering and palaeo-climate during Deccan volcanism; Palaeogeogr. Palaeoclimatol. Paleoecol. 242 90-109.

Gnandi K and Tobschall H J 2003 Distribution patterns of rare-earth elements and uranium in tertiary sedimentary phosphorites of Hahotoe-Kpogame, Togo; J. African Earth Sci. 37 1-10.

Hill I G, Worden R H and Meighan I G 2000 Geochemical evolution of a palaeolaterite: The intrabasaltic formation, northern Ireland; Chem. Geol. 166 65-84.
Huang C and Gong Z T 2001 Geochemical implication of rare earth elements in process of soil development; J. Rare Earths 19 57-62.

Inamdar P M and Darshan Kumar 1994 On the origin of bole beds in Deccan Traps; J. Geol. Soc. India 44 $331-334$.

Jerram D A and Widdowson M 2005 The anatomy of Continental Flood Basalt Provinces: Geological constrains on processes and products of flood volcanism; Lithos $\mathbf{7 9}$ $385-405$.

Laveuf C and Cornu S 2009 A review on the potentiality of rare earth elements to trace pedogenetic processes; Geoderma 154 1-12.

Lyell C 1958 On the structure of lavas, which have consolidated on steep slopes; Philosophical Transactions, Chapter XXXII, 711p.

Ma Y-J, Huo R-K and Liu C-Q 2002 Speciation and fractionation of rare earth elements in a lateritic profile from southern China: Identification of the carriers of Ce anomalies; Proceedings of the Goldschmidt Conference, Davos, Switzerland.

McLean D M 1985 Deccan Trap mantle degassing in the terminal Cretaceous Marine extinctions; Cret. Res. 6 235-259.

Mohapatra B K and Nair K K K 1996 Some observations on bole beds in Deccan Traps; Gondwana Geol. Mag. Spec. Publ. 2 531-534.

Nair K K K, Chatterjee A K and Sano T 1996 Stratigraphy and geochemistry of Deccan basalts along Toranmal section, western Satpura region; Gondwana Geol. Mag. Spec Publ. 2 23-48.

Nesbitt H W 1979 Mobility and fractionation of rare-earth elements during weathering of a granodiorite; Nature $\mathbf{2 7 9}$ 206-210.

Nesbitt H W and Markovics G 1997 Weathering of granodioritic crust, long-term storage of elements in weathering profiles, and petrogenesis of siliciclastic sediments; Geochim. Cosmochim. Acta 61 1653-1670.

Nesbitt H W and Young G M 1982 Early Proterozoic climates and plate tectonics inferred from major element geochemistry of lutites; Nature 299 715-717.

Ohta T and Arai H 2007 Statistical empirical index of chemical weathering in igneous rocks: A new tool for evaluating the degree of weathering; Chem. Geol. 240 280-297.

Pascoe E H 1973 A manual of geology of India and Burma, V.3, Govt. of India Publication, 1361p.

Reiche P 1943 Graphic representation of chemical weathering; J. Sedim. Petrol. 13 58-68.

Retallack G J 2003 Soils and global change in the carbon cycle over geological time; In: Treatise on geochemistry, Elsevier Ltd., 5 581-605.

Ronov A B, Balashov Y A and Migdisov A A 1967 Geochemistry of rare earths in sedimentary cycle; Geochem. Int. USSR 4 1-17.

Sayyed M R G and Hundekari S M 2006 Preliminary comparison of ancient bole beds and modern soils developed upon the Deccan volcanic basalts around Pune (India): Potential for palaeoenvironmental reconstruction; Quat. Int. 156-157 189-199.

Schellmann W 1986 A new definition of Laterite; In: Lateritization Processes (ed.) Banerji P K, Geol. Surv. India Memoir 120 I1-I7.

Sheldon N D 2002 Do 'red beds indicate deserts or monsoons? In: Palaeosols and Phanerozoic climate: Geochemistry to trace fossils, Denver annual meeting, Session 23.

Sheldon N D 2003 Pedogenesis and geochemical alteration of Picture Gorge Sub-Group, Columbia River basalt, Oregon; Geol. Soc. Am. Bull. 115 1377-1387. 
Sheldon N D, Retallack G J and Tanaka S 2002 Geochemical climofunctions from North American soils and application to paleosols across the Eocene-Oligocene boundary in Oregon; J. Geol. 110 687-696.

Shepard F P 1963 Submarine Geology; Harper and Row, New York, Evanston and London, 557p.

Solleiro-Rebolledo E, Sedov S, Gama-Castro J, Flores Roman D and Escamilla-Sarabia G 2003 Paleosolsedimentary sequence of the Glacis de Buenavista, Central Mexico: Interaction of Late Quaternary pedogenesis and volcanic sedimentation; Quat. Int. 106-107 185-201.

Tabor N J, Montanez I P, Zierenberg R and Currie B S 2004 Mineralogical and geochemical evolution of a basalt hosted fossil soil (Late Triassic) Ischigualastu Formation, northwest Argentina): Potential for palaeoenvironmental reconstruction; Geol. Soc. Am. Bull. 116 1280-1293.

Thiry M, Schmitt J M and Simon-Coincon R 1999 Problems, progress and future research concerning palaeoweathering and palaeosurfaces; Int. Assoc. Sedim. Spec. Publ. 27 3-17.

Topp S E, Salbu B, Roaldset E and Jørgensen P 1984 Vertical distribution of trace elements in laterite soil (Suriname); Chem. Geol. 47(1-2) 159-174.

Trivedi R K, Goel P K and Trisal C L 1987 Practical Methods in Ecology and Environmental Science; Karad, India, $350 \mathrm{p}$.
Widdowson M 1997a The geomorphological and geological importance of palaeosurfaces; In: Palaeosurfaces: Recognition, reconstruction and palaeoenvironmental interpretation (ed.) Widdowson M, Geol. Soc. Spec. Publ. 120 $1-12$.

Widdowson M 1997b Tertiary palaeosurfaces of the SW Deccan, western India: Implications for the passive margin uplift; In: Palaeosurfaces: Recognition, reconstruction and Palaeoenvironmental interpretation (ed.) Widdowson M, Geol. Soc. Spec. Publ. 120 221-248.

Widdowson M, Walsh J N and Subbarao K V 1997 The geochemistry of Indian bole horizons: Palaeoenvironmental implications of Deccan intravolcanic palaeosurfaces; In: Palaeosurfaces: Recognition, reconstruction and palaeoenvironmental interpretation (ed.) Widdowson M, Geol. Soc. Spec. Publ. 120 269-281.

Wignall P B 2001 Large igneous provinces and mass extinctions; Earth Sci. Rev. 53 1-33.

Wilkins A, Subbarao K B, Ingram G and Walsh J N 1994 Weathering regimes within the Deccan Basalts; In: Volcanism (ed.) Subbarao K, Wiley Eastern Ltd., pp. 217-231.

Yedekar D B, Aramaki S, Fujiii T and Sano T 1996 Geochemical signature and stratigraphy of the ChhindwaraJabalpur-Seoni-Mandla sector of the eastern Deccan volcanic province and problems of the correlation; Gondwana Geol. Mag. Spec. Publ. 2 49-68. 